\title{
Correction: Hydrochemical and environmental isotopes analysis for characterizing a complex karst hydrogeological system of Watuputih area, Rembang, Central Java, Indonesia
}

\author{
Taat Setiawan ${ }^{1,2} \cdot$ Boy Yoseph C. S. S. Syah Alam ${ }^{1} \cdot$ Eko Haryono $^{3} \cdot$ Hendarmawan $^{1}$
}

Published online: 1 May 2020

(C) Springer-Verlag GmbH Germany, part of Springer Nature 2020

\section{Correction: Hydrogeology Journal} https://doi.org/10.1007/s10040-020-02128-8

Figure 3 in the original article contains an error in labelling. The correct figure is given here.

The original article has been corrected.

The online version of the original article can be found at https://oi.org/ 10.1007/s10040-020-02128-8

\section{Taat Setiawan}

taat.setiawan@esdm.go.id; taat17001@mail.unpad.ac.id;

taat_setia@yahoo.com

1 Faculty of Geological Engineering, Universitas Padjadjaran, Jatinangor, Sumedang 45363, Indonesia

2 Center for Groundwater and Environmental Geology, Geological Agency, Ministry of Energy and Mineral Resources Republic of Indonesia, Diponegoro 57, Bandung 40122, Indonesia

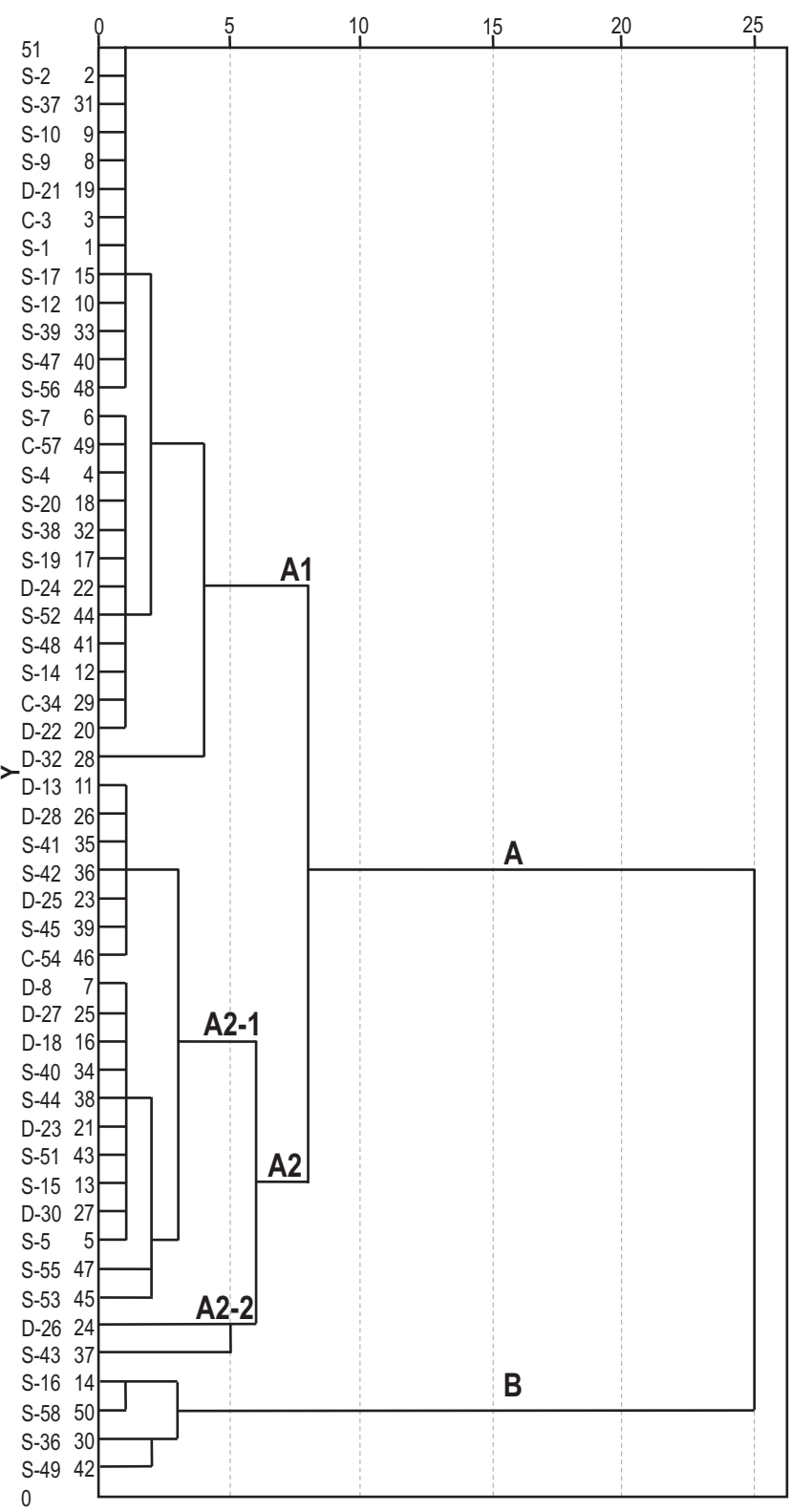

3 Faculty of Geography, Universitas Gadjah Mada, Bulaksumur, Yogyakarta 55281, Indonesia

Fig. 3 Dendrogram of water samples grouping based on hierarchical cluster analysis 